\title{
Effect of monensin sodium on fermentation efficiency in sheep rumen (short communication)
}

\section{Summary}

The efficiency of rumen fermentation was studied in lambs and wethers using 14 experimental rations with and without monensin sodium. The 7 pairs of rations (the first a control diet, the second a monensin treated one) consisted of hay and concentrate at ratios of 60:40, 40:60, 100:0, 50:50 (lambs), 100:0, 75:25 and 50:50 (wethers), respectively. The molar $\%$ of acetic, propionic, butyric and valeric acids were taken into stoichiometric calculations of rumen fermentation. In most of the rations monensin increased rumen fermentation efficiency. Of all lamb and wether rations the highest efficiency was recorded in the monensin treated ones consisting of $40 \%$ hay and $60 \%$ concentrates and $50 \%$ hay and $50 \%$ concentrates, respectively. The high fermentation efficiency was probably due to the lowest methane production observed with these rations. This means that monensin increased the amount of metabolizable energy by decreasing methane energy losses. The increase in fermentation efficiency is associated with a high production of propionic acid and in wethers also with an increase in the gross efficiency of feed conversion.

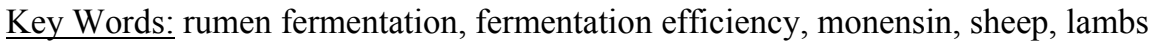

\section{Zusammenfassung}

Titel des Beitrages: Einfluss von Monensin-Gaben auf die Effizienz der Pansenfermentation beim Schaf (Kurzmitteilung)

Die Effizienz der Pansenfermentierung bei Lämmern und Widdern wurde mittels der Gabe von 14 Experimentalrationen mit und ohne Natrium Monensin untersucht. Sowohl die Kontroll- als auch die Monensinbehandelte Diät (jeweils 7 Rationen) bestanden aus Heu und Konzentrat im Verhältnis von 60:40, 40:60, 100:0, 50:50 (Lämmer), 100:0, 75:25 bzw. 50:50 (Widder). Der molare Prozentanteil von Essig-, Propion, Butter- und Valeriansäure wurde in die stoichiometrischen Berechnungen der Pansenfermentierung einbezogen. Bei den meisten Rationen wurde die Effizienz der Pansenfermentierung durch Monensin erhöht. Bei Lämmern bzw. Widdern wurde die höchste Effizienz bei den Monensin-behandelten, aus 40\% Heu und 60\% Konzentrat bzw. 50 $\%$ Heu und 50\% Konzentrat bestehenden Rationen festgestellt. Dies hängt wahrscheinlich mit der hierbei beobachteten niedrigsten Methanproduktion zusammen. Monensin erhöhte die Menge der metabolisierbaren Energie durch Reduzierung der bei der Methanproduktion entstehenden Energieverluste. Die Erhöhung der Fermentierungseffizienz ist mit der hohen Produktion von Propionsäure und bei Widdern auch mit der Erhöhung der groben Effizienz der Futterkonsversion verbunden.

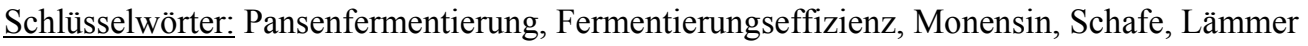

\section{Introduction}

Fermentation in the rumen is one of the specific factors determining the physiological peculiarities of ruminant digestion. The extent of the fermentation in ruminants can be calculated theoretically on the basis of volatile fatty acids (VFA) and methane production measured during fermentation. All stoichiometric calculations were based upon balance applied to the rumen fermentation (HUNGATE, 1966; DEMEYER and VAN NEVEL, 1975). ORSKOV et al. (1968) calculated the efficiency of conversion 
of hexose energy to VFA energy from basic fermentation equations and from combustion heats of hexose (glucose), acetic, propionic and butyric acid, and methane. The efforts to manipulate the rumen fermentation and to calculate the fermentation efficiency are reviewed by CHALUPA (1977).

The stoichiometric calculations are also mentioned in Technical Report Series No. 248, IAEA (1985) and reported by CZERKAWSKI (1986). They involved the fermented hexose energy into VFA energy $\left(E_{1}\right)$, methane energy $\left(E_{2}\right)$ and energy in cells $\left(\mathrm{E}_{3}\right)$, and the molar \% of acetic, propionic, butyric and valeric acid were taken into calculations.

Calculations of the rumen fermentation efficiency based on VFA and methane production are very useful when chemical agents are used to manipulate rumen fermentation via modulating selected pathways of microbial metabolism. It is known that energy in acetate, propionate and butyrate is 62,109 and $78 \%$ of that in hexose fermented. Thus the metabolically useful energy recovered in fermentation endproducts can be increased by enhancing the production of propionate and to a lesser extent butyrate at the expense of acetate production.

Several types of chemical agents are known to stimulate the propionate production in the rumen. In this work we used monensin sodium, produced by Streptomyces cinnamonensis. It was shown in vitro and in vivo that monensin increased molar proportion of propionate production and decreased the production of acetate and butyrate. (RICHARDSON et al., 1976; CHALUPA et al., 1980; SAKAUCHI and HOSHINO, 1981; WALLACE et al., 1981).

In the experiment reported in this paper monensin was added to different rations given to lambs and wethers. The objective was to investigate the effect of monensin sodium on the efficiency of rumen fermentation calculated on the basis of the molar proportion of VFA production in the rumen.

\section{Material and Methods}

Data on VFA values used for calculations of the efficiency of hexose energy conversion to energy in VFA formed were taken from experiments which investigated the effect of monensin on ruminal fermentation patterns and the performance of lambs and wethers fed diets with different ratios of roughages and concentrates. (BARAN et al., 1986a, 1986b, 1987). All these results are summarized by BARAN (1999).

The composition of rations as \% of dry matter and the doses of monensin are given in Table 1. The rations 1-8 were fed to growing lambs and rations 9-14 to adult wethers. Overall, we investigated 7 pairs of rations, where the first ration of each pair was a control and the second one was monensin treated. Monensin was added to rations 2, 4, 6, 8, 10, 12 and 14 as Rumensin 10\% premix. (Elanco Products Ltd., Indianapolis). Rations were offered in two parts ( $1 \mathrm{~kg}$ of dry matter per day) and each ration was fed to 6 animals.

In the original experiments the samples of ruminal fluid were taken before and 1, 3 and 5 hours after feeding but in this paper the values are given as means of the first, third and fifth hour after feeding. From this it follows that each value of acetate, propionate, butyrate, valerate and the efficiency of rumen fermentation $(E)$ is the mean of 18 determinations. The values of $E_{1}$ and $E_{2}$ are calculated from the mean VFA data shown in Table 2, therefore no SEM (standard error of mean) is added to these values. Individual VFAs were determined by gas chromatography (COTTYN and 
BOUCQUE, 1968). Efficiency of rumen fermentation (E) was calculated according to ORSKOV et al. (1968), efficiency of fermented hexose energy to VFA energy $\left(\mathrm{E}_{1}\right)$ and methane energy $\left(\mathrm{E}_{2}\right)$ according to CZERKAWSKI (1986) and IAEA (1985). The values of $E_{1}$ and $E_{2}$ were multiplied by 100 and the results are given in per cent. Results were statistically analysed by the t-test.

The formulas for calculations of $\mathrm{E}, \mathrm{E}_{1}$ and $\mathrm{E}_{2}$ :

$$
\begin{aligned}
& 0.622 \mathrm{~A}+1.092 \mathrm{P}+1.56 \mathrm{~B}
\end{aligned}
$$

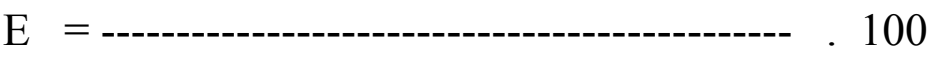

$$
\begin{aligned}
& \mathrm{A}+\mathrm{P}+2 \mathrm{~B} \\
& \begin{array}{cc}
\text { VFA energy } & 62+0.47(\mathrm{P}+2 \mathrm{~B}+2 \mathrm{~V}) \\
\mathrm{E}_{1}=\mathrm{-} & \mathrm{-} \\
\mathrm{fermented} \text { hexose energy } & (100+\mathrm{B}+\mathrm{V})
\end{array} \\
& 28-0.47(\mathrm{P}+\mathrm{V}) \\
& \begin{array}{ccc}
\mathrm{E}_{2}=\text { - } & -\mathrm{-} \text { fermented hexose energy } & (100+\mathrm{B}+\mathrm{V})
\end{array}
\end{aligned}
$$

$\mathrm{A}, \mathrm{P}, \mathrm{B}$ and $\mathrm{V}$ are the molar\% of acetic, propionic, butyric and valeric acids.

\begin{tabular}{|c|c|c|c|c|c|}
\hline $\begin{array}{c}\text { Ration } \\
\text { Hay:concentrates }\end{array}$ & $\frac{\text { Monensin }}{\left(\mathrm{mg}^{\left.-\mathrm{kg}^{-1}\right)}\right.}$ & $\begin{array}{l}\text { Acetate } \\
(\mathrm{mol} \%)\end{array}$ & $\begin{array}{l}\text { Propionate } \\
(\mathrm{mol} \%)\end{array}$ & $\begin{array}{l}\text { Butyrate } \\
(\mathrm{mol} \%)\end{array}$ & $\begin{array}{l}\text { Valerate } \\
(\mathrm{mol} \%)\end{array}$ \\
\hline 1. $60: 40$ & - & $70.8 \pm 0.48^{c}$ & $14.0 \pm 0.58^{b}$ & $12.6 \pm 0.81$ & $1.2 \pm 0.09$ \\
\hline $60: 40$ & 40 & $66.9 \pm 0.20$ & $16.6 \pm 0.47$ & $13.7 \pm 0.53$ & $1.4 \pm 0.08$ \\
\hline $40: 60$ & - & $66.3 \pm 0.47^{b}$ & $14.8 \pm 0.87^{b}$ & $16.1 \pm 0.45$ & $1.4 \pm 0.09$ \\
\hline $40: 60$ & 40 & $63.6 \pm 0.62$ & $19.4 \pm 0.92$ & $14.4 \pm 0.68$ & $1.5 \pm 0.17$ \\
\hline $\begin{array}{ll}\text { 5. } & 100: 0\end{array}$ & - & $75.4 \pm 0.59^{b}$ & $17.0 \pm 0.35^{b}$ & $5.5 \pm 0.23$ & $0.7 \pm 0.08$ \\
\hline 6. $100: 0$ & 20 & $72.2 \pm 0.57$ & $20.2 \pm 0.73$ & $5.8 \pm 0.28$ & $0.7 \pm 0.06$ \\
\hline $\begin{array}{ll}7 . & 50: 50\end{array}$ & - & $68.4 \pm 0.53$ & $15.2 \pm 0.52^{\mathrm{a}}$ & $13.7 \pm 0.87^{\mathrm{a}}$ & $1.3 \pm 0.09$ \\
\hline 8. $\quad 50: 50$ & 20 & $67.5 \pm 1.03$ & $17.8 \pm 0.84$ & $11.4 \pm 0.70$ & $1.2 \pm 0.04$ \\
\hline $\begin{array}{ll}9 . & 100: 0\end{array}$ & - & $68.9 \pm 0.51^{b}$ & $21.9 \pm 0.47^{\mathrm{c}}$ & $7.2 \pm 0.21$ & $0.7 \pm 0.04$ \\
\hline 10. $100: 0$ & 50 & $66.5 \pm 0.42$ & $25.1 \pm 0.41$ & $6.5 \pm 0.18$ & $0.7 \pm 0.04$ \\
\hline 11. $75: 25$ & - & $66.2 \pm 0.44^{b}$ & $21.6 \pm 0.54^{c}$ & $10.0 \pm 0.19$ & $0.9 \pm 0.04$ \\
\hline 12. $75: 25$ & 50 & $63.0 \pm 0.43$ & $25.3 \pm 0.45$ & $8.9 \pm 0.22$ & $0.9 \pm 0.05$ \\
\hline $\begin{array}{ll}13 . & 50: 50\end{array}$ & - & $65.2 \pm 0.71^{c}$ & $16.5 \pm 0.83^{c}$ & $15.5 \pm 0.26^{b}$ & $1.1 \pm 0.08$ \\
\hline 14. $50: 50$ & 50 & $61.0 \pm 0.54$ & $26.2 \pm 0.61$ & $9.5 \pm 0.25$ & $1.0 \pm 0.06$ \\
\hline
\end{tabular}

Table 1

The rations, monensin doses and the mean values ( \pm SEM) of VFA (Futterration, Monensindosis und Mittelwerte der FFS ( \pm SEM))

\section{Results and Discussion}

The results are shown in Table 1, where the mean values of acetate, propionate, butyrate and valerate are shown, and in Table 2 containing the mean values of $\mathrm{E}, \mathrm{E}_{1}$ and $\mathrm{E}_{2}$. In comparison of all rations fed to lambs, the highest fermentation efficiency $(\mathrm{E}=74.44 \%)$ was calculated in ration 4 consisting of hay and concentrates $40: 60$ with addition of $40 \mathrm{mg}$ of monensin. The lowest fermentation efficiency ( $E=71.61 \%)$ was measured in ration 5 consisting only of hay. In correlation to these results there are the values of the efficiency of fermented hexose to methane $\left(E_{2}\right)$ which were lowest in ration 4 and highest in ration 5 . This confirmed the positive effect of monensin on 
rumen fermentation. The high fermentation efficiency in ration 4 was probably due to the lowest methane production. This means that monensin could increase the amount of metabolizable energy by decreasing methane energy losses.

Table 2

The mean values $( \pm$ SEM) of the rumen fermentation efficiency (Mittelwerte $( \pm$ SEM) der Effizienz der Pansenfermentierung)

\begin{tabular}{|c|c|c|c|}
\hline Ration: & $\begin{array}{c}\mathrm{E} \\
(\%)\end{array}$ & $\begin{array}{l}E_{1} \\
(\%)\end{array}$ & $\begin{array}{c}E_{2} \\
(\%)\end{array}$ \\
\hline 1 & $71.8 \pm 0.18^{c}$ & $72.2^{b}$ & 18.3 \\
\hline 2 & $73.1 \pm 0.12$ & 73.5 & 17.0 \\
\hline 3 & $72.8 \pm 0.29^{b}$ & $73.2^{c}$ & 17.3 \\
\hline 4 & $74.4 \pm 0.36$ & 74.9 & 15.7 \\
\hline 5 & $71.6 \pm 0.19^{b}$ & $71.7^{b}$ & 18.5 \\
\hline 6 & $73.1 \pm 0.31$ & 73.1 & 17.1 \\
\hline 7 & $72.5 \pm 0.16$ & 72.9 & 17.6 \\
\hline 8 & $73.3 \pm 0.38$ & 73.5 & 16.9 \\
\hline 9 & $74.1 \pm 0.20^{c}$ & 74.2 & 16.1 \\
\hline 10 & $75.5 \pm 0.28$ & 75.4 & 14.8 \\
\hline 11 & $74.7 \pm 0.22^{b}$ & $74.7^{b}$ & 15.7 \\
\hline 12 & $76.9 \pm 0.39$ & 76.0 & 14.3 \\
\hline 13 & $73.4 \pm 0.51^{c}$ & $73.7^{c}$ & 16.9 \\
\hline 14 & $76.7 \pm 0.49$ & 76.6 & 13.7 \\
\hline
\end{tabular}

Monensin positively influenced the fermentation efficiency in rations 1-2, 3-4 and 5-6. On the other hand it is interesting that monensin had a positive effect in all roughage rations (5-6) and no effect in rations 7-8 consisting of hay and concentates 50:50\%. The best results in lamb rations were obtained with diets 3-4 (hay $40 \%$, concentrates $60 \%)$.

However, when comparing the effect of monensin on wether rations we obtained the best results in rations 13-14, where the ratio of hay and concentrates was 50:50. An increase in fermentation efficiency in wether rations with addition of monensin is associated with an increase in the gross efficiency of feed conversion, which is highest in ration 14 (BARAN et al., 1986a) and also with a high molar \% of propionic acid (Table 2). The increase in propionic acid or change in the molar proportion of VFA in favour of propionate, are typical effects of monensin on rumen fermentation (RICHARDSON et al., 1976; CHALUPA et al., 198O,; HORTON et al., 1983; BARAN et al., 1986a). This favourable effect of monensin was more increased in adult wethers than in growing lambs, when monensin influenced favourably the rumen efficiency, but had no effect on lamb production parameters. Average daily gains and feed conversion in lambs were higher or better in rations with monensin but they were not significant (BARAN et al., 1986a).

The advantages of energy efficiency methods of ORSKOV et al. (1968) and CZERKAWSKI (1986) are described in their original papers. We consider the method (E) of ORSKOV et al. (1968) better for in vivo studies and the method $\left(\mathrm{E}_{1}\right)$ of CZERKAWSKI (1986) better for in vitro studies, but the differences are very small. The methods are based always on the production and interrelationship of VFA.

In evaluating the results of this experiment, monensin sodium as growth promotor increased the fermentation efficiency and was a useful parameter when determining VFA. 


\section{Acknowledgments}

This work was founded by Slovak Scientific Grant Agency (VEGA Grant Project $1165 / 21)$

\section{References}

BARAN, M.; BODA, K.; SIROKA, P.:

The effect of monensin on rumen fermentation in sheep fed on all-roughage and barley/roughage diets. Anim. Feed Sci. Technol., 15 (1986a), 7-12

BARAN, M.; BODA, K.; JALC, D.; SIROKA, P.; KALACHNYUK, G.I.; ALFONZO, O.:

Performance of fattening lambs given monensin with different levels of concentrates. Summaries of $4^{\text {th }}$ World Congress of Animal Feeding, Symp. Ruminants S-I-35, Madrid (1986b), 45

BARAN, M.; KALACHNYUK, G.I.; SIROKA, P.; JALC, D.:

Rumen fermentation in lambs given monensin with roughage or concentrate diets. Veter. Med.

BARAN, M.: (Prague),32,1987,suppl. 20-21

Chemical and dietary effects on rumen fermentation in ruminants. DSc Thesis, Institute of Animal Physiology, Slovak Academy of Sciences, Kosice, 1999

CHALUPA, W.: Manipulating rumen fermentation. J. Anim. Sci., 46 (1977), 585-599

CHALUPA, W.; CORBETT, W.; BRETHOUR, J.R.:

Effects of monensin and amicloral on rumen fermentation. J. Anim. Sci. 51 (1980), 170-179

COTTYN, B.G.S.; BOUCQUE, C.V.:

Rapid method for the gas chromatographic determination of volatile fatty acids in rumen fluid. J. Agric. Food Chem. 16 (1968), 105-107

CZERKAWSKI, J.W.:

An Introduction to Rumen Studies. Pergamon Press, Oxford (1986), 221-222

DEMEYER, D,I.; VAN NEVEL, C.J.:

Methanogenesis, an integrated part of carbohydrate fermentation, and its control. In: I.W. McDONALD, C.I. WARNER (eds), Digestion and Metabolism in the Ruminant, University of New England Publishing Unit, Armidale (1975), 366

HORTON, G.H.J.; FARMER, M.J.; BASSENDOWSKI, K.A.; STEACY, G.M.:

Rumen fermentation and digestibility in steers as influenced by levels of intake and monensin. Can.J.Anim.Sci. 63 (1983), 855-860

HUNGATE, on the subject of.: The Rumen and its Microbes, Academic Press, New York (1966)

INTERNATIONAL ATOMIC ENERGY AGENCY:

Laboratory Training Manual on the Use of Nuclear Techniques in Animal Nutrition, Technical Reports Series No.248 IAEA, Vienna (1985), 301

ORSKOV, E.R.; FLATT, W.P.; MOE,P.W.:

Fermentation balance approach to estimate extent of fermentation and efficiency of volatile fatty acids formation in ruminants. J. Dairy Sci. 51 (1968), 1429-1435

RICHARDSON, L.F.; RAUN, A.P.; POTTER, E.L.; COOLEY, C.O.; RATHMACHER, R.P.:

Effect of monensin on rumen fermentation in vitro and in vivo. J .Anim. Sci., 43 (1976), 657-664

SAKAUCHI, R.; HOSHINO,S.;

Effects of monensin on ruminal fluid viscosity, $\mathrm{pH}$, volatile fatty acids and ammonia levels, and microbial activity and population in healthy and bloated feedlot steers. Z. Tierphysiol. Tierernähr. Futtermittelkunde 46 (1981), 21-33

WALLACE, R.J.; CZERKAWSKI, J.W., BRECKENRIDGE, G.:

Effect of monensin on the fermentation of basal rations in the Rumen Simulation Technique (Rusitec). British. J. Nutr. 46 (1981), 131-148

Received: 2001-03-15

Accepted: 2002-03-01

Corresponding author

Dr. MIROSLAV BARAN, DSc.

Institute of Animal Physiology, Slovak Academy of Sciences

Soltésovej 4-6

04001 Košice, Slovakia 